DOI: https://doi.org/10.18371/fp.3(39).2020.215179

УДК 330.322

\title{
ОЦІНЮВАННЯ ІНВЕСТИЦІЙНОЇ ПРИВАБЛИВОСТІ ДЕРЖАВНИХ КОМПАНІЙ: ВИКЛИКИ ДЛЯ ПРОЗОРОСТІ ТА КОРПОРАТИВНОЇ СОЦІАЛЬНОЇ ВІДПОВІДАЛЬНОСТІ
}

\author{
ЄЛЬНІКОВА Юлія Василівна \\ кандидат економічних наук, \\ стариий науковий співробітник, Сумський державний університет \\ ORCID ID: http://orcid.org/0000-0002-8478-4716 \\ e-mail :yelnikovad@gmail.com
}

\begin{abstract}
Анотація. $Y$ cmaтmi розглянуто суmність та необхідність оиінювання інвестиичійної привабливості державних компаній України. В основу оцінювання покладено модель фінансової стійкості компаній Д. Піотроскі. Доведено, щзо низька інвестииійна привабливість державних компаній Украӥни обумовлена не лиме їх низькою фінансовою стійкістю, але й низькою прозорістю діяльності та недостатнім впровадженням ініичіатив корпоративної соціальної відповідальності ичих компаній.

Ключові слова: інвестииійна привабливість, оцінка, прозорість, корпоративна соціальна відповідальність.
\end{abstract}

Постановка проблеми. 3 переходом до ринкової економіки інвестиції стали невід'ємною частиною економічного зростання в Україні. Фактично вони визначають майбутне держави в цілому на різних рівнях розвитку в будь-якій країні, служить основою для розширеного процесу відтворення, більш інтенсивних інновацій поліпшення якості продукції та забезпечення іiі конкурентоспроможності, оновлення асортименту та пропозиції товарів та послуг, зниження собівартості та реалізації, збільшення про-
Аннотация. $B$ cmaтье рассмотрены сущ ность и необходимость оценки инвестиционной привлекательности государственных компаний Украины. В основу оценки положена модель финансовой устойчивости компаний Д. Пиотроски. Доказано, что низкая инвестиционная привлекательность государственных компаний Украинь обусловлена не только их низкой финансовой устойчивостью, но и низкой прозрачностью деятельности и недостаточным внедрением инициатив корпоративной сочииальной ответственности этих компаний.

Ключевые слова: инвестиичонная привлекательность, оченка, прозрачность, корпоративная сочиильная ответственность.

дажів та прибуток. Саме тому дуже важливим є процес оцінювання інвестиційної діяльності державних компаній для зменшення ймовірних ризиків та прогнозування позитивного економічного ефекту, особливо у контексті їх специфічної ролі у соціальновідповідальній діяльності та здійсненні відповідальних інвестицій.

Аналіз останніх досліджень та публікацій. Дослідженням у галузі теоретичних та практичних аспектів оцінки інвестиційної привабливості підприємств присвятили свої праці 
такі українські вчені, як Т.М. Власюк [5], Л. І. Катан, К.С. Хорішко [7], Н.С. Крупська [8], Т.В. Майорова [9], В.М. Микитюк [11], І.К. Федоренко [15], С.В. Юхимчук [17]. Проте, дослідження, які розкриваються дане питання наразі лише набувають поширення та не включають в себе всі елементи реальної оцінки інвестиційної привабливості державних компаній в сучасному середовищі розвитку національного господарства 3 урахуванням їх прозорості та корпоративної соціальної відповідальності (КСВ).

Метою статті $€$ дослідження оцінювання інвестиційної привабливості державних компаній: викликів для прозорості та корпоративної соціальної відповідальності.

Виклад основних результатів дослідження. Відповідно до проаналізованої теоретичної бази щодо дослідження інвестиційної привабливості державних компаній слід зазначити, що, незважаючи на адекватну тематичну спрямованість (вивчення інвестиційної привабливості та фінансової ефективності компаній через межі їх діяльності 3 КСВ та прозорості), включення в дослідження державних компаній $\epsilon$ епізодичним.

Окрім досліджень інвестиційної привабливості, залежності фінансової ефективності компанії від їх КСВ, проведених науковцями, авторитетні організації теж проводять рейтингові дослідження у цій сфері.

Серед найбільших за вибіркою досліджень слід назвати:

- рейтинг проекту «Сприяння прозорості та впровадження антикорупційних заходів у державних підприємствах та органах місцевого самоврядування в Україні», створений Мiжнародним центром перспективних досліджень (МЦПД) у партнерстві 3 Інститутом економічних і соціальних реформ (INEKO). Ініціатива фінансується Офіційною Підтримкою Розвитку Словацької Республіки (SlovakAid) (50 найбільших державних компаній були відібрані за показником "Загальна вартість активів” та частка держави становить більше 51\%, 2019 р) [13];

- дослідження «Прозорість корпоративної звітності». Оцінка найбільших приватних і державних компаній, проведених експертами Transparency International Україна (50 державних українських компаній зі списку «100 найбільших державних підприємств України за 6 місяців 2015 року», що оприлюднило Міністерство економічного розвитку і торгівлі, 2016 р. [14]

- індекс прозорості державних компаній - 2015 (38 державних компаній які увійшли до Рейтингу ТОП100 найбільших компаній України по рівню доходу та компанії, щодо яких Уряд України запланував провести державний фінансовий аудит окремих господарських операцій (Постанова Кабінету Міністрів України від 25 червня 2014 р.№ 214) та індекс прозорості найбільших українських компаній - 2017 (20 державних компаній, які увійшли до топ-100 найбільших платників податків в Україні у 2017 році за даними Державної фіскальної служби [1].

Рейтинг (МЦПД - INEKO) базується на показнику загальної прозорості за 50 державними компаніями, що оцінюється в межах від F (0 \% - $9 \%$ до $\mathrm{A}+(80 \%-100 \%)$ та формується 3 урахуванням наступних складових:

- прозорість та доступ до інформації;

$$
\text { - економічні показники; }
$$


- державні закупівлі та власність;

- кадрова політика;

- етика та конфлікт інтересів;

- гранти та благодійна політика.

Оцінювання прозорості Transparency International Україна відбувалось за 3 тематичними блоками за 10 бальною шкалою:

- розкриття антикорупційної програми;

- організаційна прозорість

- розкриття інформації про діяльність та операції в інших країнах.

Обидва дослідження Центру розвитку КСВ у 2015 та 2017 рр. спирались на подібні показники за 100 бальною шкалою: у 2015 р. - зміст (наявність на сайті компанії КСВ), стратегія та звітність (наявність бізнес-стратегії й стратегії з КСВ), навігація (зручність доступу до будь-якої інформації про КСВ; у 2017 - звітність, зміст, навігація та доступність.

Усі названі дослідження вказують на недостатній рівень прозорості та сприяння КСВ державних компаній. По-перше, у рейтинг (МЦПД (INEKO) жодна 3 державних компаній не набрала оцінки вище В- (при максимальних A - 100\%); по-друге, середній рівень прозорості державних компаній у рейтингу ТІ дорівнює 3.1 одиниць; по-третє, індекс прозорості і підзвітності державних компаній Центру розвитку КСВ у 2015 р. становив 19,3\% зі $100 \%$, у 2017 - 24\% зі 100\%. Спільною характеристикою названих досліджень, крім низької прозорості компаній державного сектору, не зважаючи на різницю в методології, $\epsilon$ наявність одного й того ж лідера ДП «Національна атомна енергогенеруюча компанія «Енергоатом», що значно випереджає усі компанії рейтингів.
Підсумовуючи проаналізовані рейтинги прозорості та КСВ компаній, слід зауважити, що не зважаючи на включення до аналізу державних компаній чи фокусування виключно на них, зазначені дослідження не враховують досить критичної складової для формування інвестиційної привабливості державних компаній - фінансових показників ефективності.

Продовжуючи дослідження зарубіжних та вітчизняних науковців та рейтингових організацій у сфері інвестиційної привабливості, прозорості та КСВ компаній державного сектору як ключових агентів держави на ринку ВI проведемо оцінювання їх інвестиційної привабливості $з$ подальшим співставленням з їх діяльністю у сфері КСВ та рівнем прозорості.

Для дослідження було відібрано 25 найбільших державних підприємств України за 2017-2018 pр. за часткою активів серед державних компаній за даними Міністерства економічного розвитку та торгівлі з регулярних звітів «Топ -100 державних компаній» [2].

Обгрунтування вибору саме цих 25 компаній для дослідження інвестиційної привабливості державних компаній для ВI полягає у тому, що зазначена вибіркова сукупність задовольняє критерію репрезентативності. Частка активів вказаних компаній досягає 92,5 \% від сукупних активів компаній державного сектору.

Слід зауважити, що абсолютні показники, які характеризують досліджувані 25 компаній, не можуть бути використані повною мірою як мірило інвестиційної привабливості, оскільки $\epsilon$ статичними і не враховують динаміку розвитку компаній. Галузева струк- 
тура досліджуваних компаній представлена на рис. 1.
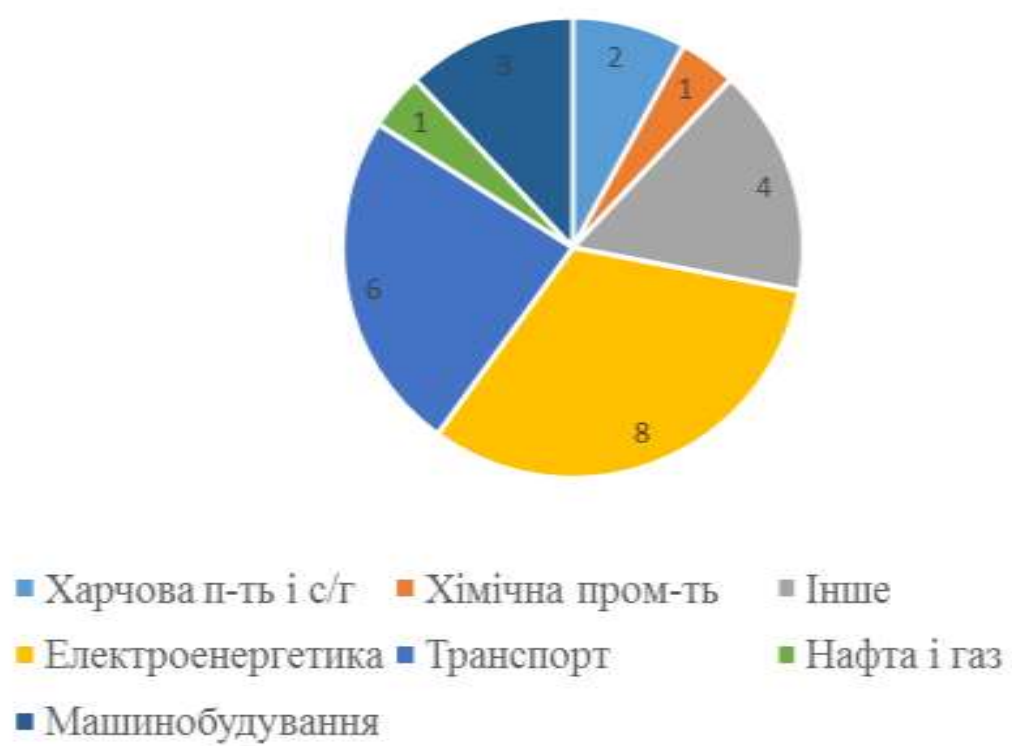

Рис. 1. Галузева структура вибіркової сукупності державних компаній Джерело: складено автором

Не зважаючи на максимізацію абсолютних показників фінансової ефективності окремими державними компаніями у 2018 р., в динаміці вони можуть мати негативні значення.

Зокрема на агрегованому рівні за досліджуваними підприємствам спостерігається: 1) скорочення балансової вартості активів (у 2018 р. їх вартість становила 486 млрд грн, що на 6,4\% менше, ніж у 2017 році); 2) скорочення чистого прибутку до 25,3 млрд грн, що на 48,2\% менше показника 2017 року; 3) зменшення прибутку характерно для таких стратегічних галузей національної економіки як нафта і газ, транспорт, вугільна промисловість [12].

Зазначені показники свідчать про погіршення інвестиційної привабливості компаній державного сектору в абсолютному вимірі. Для проведення комплексного аналізу інвестиційної привабливості державних компаній абсолютні показники необхідно допо- внити відносними показниками фінансової ефективності та їх аналізом в динаміці. Таким чином, авторська методика оцінювання інвестиційної привабливості державних компаній для ВI має 2 етапи:

1) Розрахунок фінансової складової інвестиційної привабливості державних компаній на основі усебічного аналізу абсолютних та відносних показників їх фінансової ефективності в динаміці;

2) Співставлення отриманих результатів 3 показниками КСВ та прозорості діяльності досліджуваних компаній для визначення впливу вказаних параметрів на інвестиційну привабливість.

Зазначена методика поєднує позитивні риси досліджень науковців щодо впливу КСВ та прозорості на фінансову ефективність компаній та результати рейтингування державних компаній за цими параметрами. 
Як методологічне підгрунтя оцінювання інвестиційної привабливості державних компаній України у 20172018 рр. було обрано модель оцінювання фінансової стійкості компаній моделі Piotroski F-score (Д. Піотроскі), що враховує як абсолютні, так і відносні показники ефективності компаній в динаміці за вимірами: прибутковість, ліквідність та операційна діяльність [4].

До переваг вказаної моделі оцінювання інвестиційної привабливості компаній можна віднести однозначність інтерпретації як 9 розрахункових критеріїв (1 бал у разі відповідності державної компанії критерію; 0 - у разі невідповідності), так і загальної оцінки інвестиційної привабливості (при значенні F-score 8-9 компанію можна віднести до фінансово стійкої та інвестиційно привабливої; при значенні F-score 0-2 компанію можна віднести до фінансово нестійкої та інвестиційно непривабливої).

Модель базується на розрахунку таких показників:

- ROA>0 в поточному році. Позитивна рентабельність активів (Return on Assets) в поточному році.

- $\mathrm{OCF}>0$ в поточному році. Позитивний грошовий потік від операційної дільності (Operating Cash Flow) в поточному році.

- ROAt> ROAt-1. Рентабельність активів в цьому році більше ніж в попередньому.

- OCF / TA> ROA. Відношення грошового потоку від операційної діяльності до загальних активів (Total Assets) більше значення рентабельності активів в цьому році.

- LTDt <LTDt-1. Коефіцієнт довгострокової заборгованості (Long
Term Debt) в цьому році нижче, ніж в попередньому.

- CRt> CRt-1. Коефіцієнт поточної ліквідності (Current Ratio) в цьому році більше ніж в попередньому.

- Нові акції не випускалися (не було додаткової емісії) (Additional emission $\mathrm{AE}$ ).

- GMt> GMt-1. Валовий прибуток (Gross Margin) цього року більше, ніж попереднього.

- ATRt> ATRt-1. Коефіцієнт оборотності активів (Asset Turnover Ratio) цього року більше ніж в попередньомy. [3].

Проведені розрахунки значення Fscore за 25 державними компаніями загалом свідчать про їх низьку інвестиційну привабливість, що обумовлена передусім низькою фінансовою ефективністю діяльності компанії в абсолютному та відносному вимірах. Жодна 3 компаній не досягла 8-9 балів за шкалою F-score, що свідчило б про iii фінансову стійкість та доцільність здійснення в неї інвестицій. Лише 3 компанії ПрАТ «Укргідроенерго», ПАТ «Турбоатом» та ПАТ «Аграрний фонд» мають найвищі значення $\mathrm{F}$ score - 7 балів та наближаються до фінансово стійких компаній. Їх спільними рисами є позитивний фінансовий результат протягом 2017-2018 рр, додатний рух грошових коштів від операційної діяльності, зростання рентабельності активів та коефіцієнту їх оборотності, а також відсутність додаткових емісій акцій.

Разом 3 тим і абсолютно нестійких компаній серед 25 державних компаній лише 3 - ПАТ «Державна продовольчо-зернова корпорація України», ПАТ «Одеський припортовий завод», ДП «Східний гірничо-збагачувальний комбінат». Збитки за цими компаніями 
мають тенденцію до скорочення, що дозволяє говорити про ймовірний їх вихід 3 групи 3 найнижчими значеннями F-score. Окрім того, жодна 3 компаній не вдавалася до доемісії власного капіталу для поліпшення становища.

Слід також зауважити, що галузева структура досліджуваних компаній не має впливу на показники інвестиційної привабливості, оскільки компанії харчової промисловості та сільського господарства представлені як серед лідерів за значеннями F-score в Україні, так й інвестиційно непривабливих компаній.

Проведення співставлення показників інвестиційної привабливості та рейтингових оцінок в сфері КСВ та прозорості державних компаній України дозволило зробити висновок про відсутність достатніх умов для врахування КСВ діяльності та прозорості цих компаній як детермінант їх фінансової стійкості, ефективності та інвестиційної привабливості.

Оскільки відсутня будь-яка закономірність у розподілі рейтингових оцінок прозорості та КСВ державних компаній та їх інвестиційної привабливості.

Зазначена теза підтверджується i розрахунками коефіцієнту кореляції між показником фінансової стійкості державних компаній (F-score) та їx оцінкою у рейтингу 2019 р. При цьому сам коефіцієнт становить 8,1\%, a Fстатистика свідчить про його статистичну адекватність.

Навіть лідер усіх національних рейтингів 3 прозорості, КСВ державних компаній - ДП «Національна атомна енергогенеруюча компанія «Енергоатом» має недостатньо фінансово стійкий стан, що обумовлено передусім відсутністю позитивного грошового потоку від операційної діяльності, низьким значенням коефіцієнтів поточної ліквідності та відношення грошового потоку від операційної діяльності до загальних активів.

Лідери за показниками інвестиційної привабливості мають недостатньо високі рейтингові оцінки КСВ та прозорості, що не дає можливості говорити про доцільність здійснення ВІ в ці компанії. Зокрема, ПАТ «Аграрний фонд» взагалі не представлений серед рейтингів Центру розвитку КСВ, а рівень його прозорості у рейтингу ТI близький до середнього за усіма державними компаніями. Інші 2 компанії (ПрАТ «Укргідроенерго» та ПАТ «Турбоатом» займають також доволі посередні місця у аналізованих рейтингах.

Значення рейтингу прозорості державних компаній за проектом «Сприяння прозорості та впровадження антикорупційних заходів у державних підприємствах та органах місцевого самоврядування в Україні» (МЦПД INEKO), близькі до медіанного значення за усією сукупністю державних компаній характерні для ПАТ «Одеський припортовий завод» та ПАТ «Укрпошта». Однак, ці компанії мають найнижчі значення показників фінансової стійкості та інвестиційної привабливості. Подібна ситуація характерна i для групи компаній 3 посередньою інвестиційною привабливістю i близькими до медіанних значень рейтингу прозорості у 2019 р. (ПАТ «Центренерго», ДП «Украерорух», ПАТ «Державна акціонерна компанія «Автомобільні дороги України», АК «Харківобленерго», ПАТ «Укрзалізниця»). 
Висновки. Таким чином, не зважаючи на статус державних компаній як провідників цінностей сталого розвитку та адептів ідеології відповідального інвестування, що прослідковується виходячи 3 досвіду розвинених країн світу та країн, що розвиваються (зокрема Китаю), в Україні державні компанії не мають таких характеристик.
Досліджені 25 найбільших державних підприємств за часткою активів мають не лише низьку фінансову стійкість (визначену за моделлю F-score), але й недостатню інвестиційну привабливість для здійснення відповідальних інвестицій з огляду на відсутність впливу на фінансову ефективність КСВ діяльності та прозорості.

\section{Список використаної літератури}

1. 100 найбільших державних підприємств України за 2017 рік (звіт). URL: https://www.me.gov.ua/Documents/Download?id=0a6ff86b-5bce-4fa5-b06a511d2a29d0d0 (дата звернення 10.08.2020)

2. 100 найбільших державних підприємств України за 2018 рік (звіт). URL: https://issuu.com/mineconomdev/docs/__100_-_2018 (дата звернення 10.08.2020)

3. Piotroski f-score (модель Пиотроски). Оценка финансовой устойчивости. URL: https://finzz.ru/f-score.html (дата звернення 10.08.2020)

4. Piotroski J. D. Value Investing: The Use of Historical Financial Statement Information to Separate Winners from Losers. The University of Chicago Graduate School of Business. 2013. URL: http://www.chicagobooth.edu/ / media/FE874EE65F624AAEBD0166B1974FD74D.pdf (дата звернення 10.08.2020)

5. Власюк Т.М. Методика оцінки інвестиційної привабливості державних підприємств. Інвестиції: практика та досвід. 2005. №4. С. 22-26.

6. Зінченко А., Резнік Н., Саприкіна М. Індекс прозорості сайтів українських компаній 2017. Київ: Видавництво «Юстон», 2018. 28 с.

7. Катан Л.І., Хорішко К.С. Оцінка інвестиційної привабливості підприємства. Інвестищії: практика та досвід. 2010. №5. С. 22-24.

8. Крупська Н.Є., Бахір О.О. Формування рейтингової оцінки інвестиційної привабливості підприємств, 2010. URL: www.rusnauka.com. (дата звернення 10.08.2020)

9. Майорова Т.В. Інвестиційна діяльність: навч. посібник. Київ: ЦУЛ, 2003. $376 \mathrm{c}$.

10. Макарій Н. Оцінка інвестиційної привабливості українських підприємств. Економіст. 2001.№10. С. 52-60. 
11. Микитюк В.М., Трофименко Н.В. Оцінка інвестиційної привабливості аграрних підприємств. Вісник Житомирського начіонального агроекологічного університету. 2011. №1, Т. 2. С. 305-311.

12. Міністерство розвитку економіки, торгівлі та сільського господарства України. URL: https://me.gov.ua/News/Detail?lang=uk-UA\&id=5b766e9d-5da7411a-9037-7085c5da1bca\&title=Top100-DerzhavnikhPidprimstvU2018RotsiOtrimaliZagalniiPributokV25-3-MlrdGrn\&isSpecial=true (дата звернення 10.08.2020).

13. Прозорість державних підприємств. URL: http://companies.icps. com.ua/data\#section-1-0 (дата звернення 10.08.2020).

14. Прозорість корпоративної звітності: оцінка найбільших приватних та державних компаній України. URL: https://ti-ukraine.org/news/62-top-kompaniiukrainy-daleki-vid-standartiv-prozorosti-ti-ukraina/ (дата звернення 10.08.2020) 15. Федоренко І.К., Рибалко В.Б. Моделювання інвестиційної привабливості компаній методами факторного аналізу. Формування ринкових відносин в Україні. 2010. №10. С. 89-93.

16. Центр розвитку КСВ Індекс прозорості державних компаній України, 2015. URL: http://www.energoatom.com.ua/files/file/transparency_index_2015.pdf (дата звернення 10.08.2020).

17. Юхимчук С.В., Супрун С.Д. Матрична модель оцінки інвестиційної привабливості промислових підприємств. Фінанси України. 2003. №1. С. 3-12. 